\title{
Effect of Lipopolysaccharide (from Escherichia coli) on the Hepatic Drug-Metabolizing Activities in Successively LPS-Treated Mice
}

\author{
Ken-ichi SASAKI, Masaaki ISHIKAWA-SAITOH and Giichi TAKAYANAGI \\ Cancer Research Institute, Tohoku College of Pharmaceutical Sciences, \\ Komatsushima, Sendai 983, Japan
}

Accepted October 29, 1983

\begin{abstract}
The effect of an acute or a successive administration of endotoxin (lipopolysaccharide obtained from Escherichia coli. LPS) on the hepatic drugmetabolizing system in vivo and in vitro was examined in mice. An acute LPS (5 $\mathrm{mg} / \mathrm{kg}$, i.v.) administration or a successive LPS $(5-20 \mathrm{mg} / \mathrm{kg}$, i.p., a day for 6 days) administration prolonged the duration of pentobarbital sleeping time and reduced the rate of hepatic microsomal metabolism of pentobarbital, aminopyrine, aniline and cyclophosphamide and reduced cytochrome P-450 content as compared with those in the control mice. No change of these parameters, however, was observed by an acute treatment with LPS to the successively LPS-treated mice. In addition, the LD50's of aminopyrine and pentobarbital and the ED50 of aminopyrine were reduced by an acute administration of LPS in control mice. No change of both parameters, however, was observed in the successively LPS-treated mice with or without an acute administration of LPS.
\end{abstract}

Some immunopotentiators such as Bacillus Calmette-Guérin. lipopolysaccharide and Corynebacterium parvum are known to exert a wide variety of effects on hepatic function (1-3), especially on the hepatic drug-metabolizing enzyme system (4-9). Endotoxin (lipopolysaccharide obtained from Escherichia coli. LPS) is a potent inhibitor of the hepatic microsomal drug-metabolizing enzymes in rats (6) and mice (7-9). This decrease in the enzyme activity is due to a decrease in synthesis of the hemoprotein and an increase in its degradation (9-11). Although the endotoxin tolerance was induced by a successive treatment with LPS, very few studies have been done on its effect on the hepatic drug-metabolizing enzyme system. Since the acute effect of a drug on this system may differ from the successive effect of a drug $(12,13)$, we studied the effects of acute and successive LPS treatments on in vivo drug metabolism by measuring the sleeping time induced by pentobarbital and on in vitro drug metabolism by measuring cyclophosphamide activation, pentobarbital oxidase, aminopyrine $N$ demethylase, aniline hydroxylase, NADPHcytochrome $c$ reductase and cytochrome P-450 content. Pentobarbital was selected for the reason that the duration of its action is regulated by the activity of the hepatic drugmetabolizing enzyme system (14).

\section{Materials and Methods}

Drugs: LPS was purchased from Difco Co. It is a freeze-dried material of lipopolysaccharide extracted from Escherichia coli. All other chemicals and reagents were of the highest commercially available purity.

Animals: Male ddY mice weighing 22-24 g at the start of the experiments were used in all studies. The animals were housed in community cages for at least 3 days prior to use. They were fed on commercial laboratory chow (CE-2. Nippon Clea) and given tap water ad libitum. The tolerance to LPS was induced by the successive administration of higher doses of LPS for 6 days according to 
the method of Berry and Smythe (15). Control animals received the equal volume of saline. The effect of a single administration of LPS ( $5 \mathrm{mg} / \mathrm{kg}$, i.v.) on Day 7 was studied $24 \mathrm{hr}$ after the administration of LPS.

Assay of enzyme activity: Pentobarbital oxidase, aniline hydroxylase, aminopyrine $N$ demethylase and NADPH-cytochrome $c$ reductase activities and cytochrome P-450 content were determined as described earlier $(7,8)$. The cyclophosphamide activating enzymes in liver were determined by the method of Hart et al. and Sladek $(16,17)$. Protein concentrations were estimated by the method of Lowry et al. (18).

Determination of blood sugar: The blood sugar was measured by the o-toluidine method using glucose as the standard (19).

All results are expressed as the means $\pm S$. E. The $t$-test was used to compare difference between the means.

Analgesic action: The acetic acid-writhing method in mice was employed. Frequency of writhing movements induced by an intraperitoneal injection of $0.7 \%$ acetic acid was counted from $10 \mathrm{~min}$ to $20 \mathrm{~min}$ after the injection. Thirty min after the injection of a test drug, acetic acid was injected and the inhibitory rate was obtained by comparing the frequency of writhing movements with those of the saline control. The ED50's and their $95 \%$ confidence limits were determined by the method of Litchfield and Wilcoxon.

Lethality: Lethality was observed $72 \mathrm{hr}$ after the intraperitoneal injection of aminopyrine and pentobarbital or 30 days after the intraperitoneal injection of cyclophosphamide. The LD50's and their 95\% confidence limits were determined by the method of Litchfield and Wilcoxon.

\section{Results}

Effect of LPS on the pentobarbitalinduced hypnosis in the successively LPStreated mice: The data in Fig. 1 depict the effect of LPS ( $5 \mathrm{mg} / \mathrm{kg}$, i.v.) on the hypnotic response induced by pentobarbital and the hepatic microsomal biotransformation of pentobarbital in the control mice and the successively LPS-treated mice. As shown in Fig. 1, in the control mice, LPS produced a significant prolongation in the duration of hypnosis induced by pentobarbital $(50 \mathrm{mg} /$ $\mathrm{kg}$, i.p.) which correlated with a significant decrease in the rate of drug biotransformation.

When $5 \mathrm{mg} / \mathrm{kg}$ (i.v.) of LPS was administered to the control mice, the sleeping time induced by pentobarbital was $324.8 \mathrm{~min}$. This time was 6 times as long as that in the control mice.

Also, the successive LPS treatment significantly prolonged the duration of hypnosis induced by pentobarbital and decreased the rate of drug biotransformation. The duration of hypnosis induced by pentobarbital ( $50 \mathrm{mg} / \mathrm{kg}$, i.p.) in the acutely LPS $(5 \mathrm{mg} / \mathrm{kg}$. i.v.)-treated mice was significantly longer than that in the successively LPS-treated mice.

A single administration of LPS $(5 \mathrm{mg} / \mathrm{kg}$, i.v.) after the successive treatment with LPS, however, did not cause a significant prolongation in the duration of hypnosis induced by pentobarbital and decrease in rate of the drug biotransformation as compared with those in the successively LPS-treated mice.

Effect of LPS on the drug-metabolizing system in the successively LPS-treated mice: As shown in Table 1, when $5 \mathrm{mg} / \mathrm{kg}$ (i.v.) of LPS was administered to the control mice, the activities of hepatic drug-metabolizing enzymes and protein of the liver were significantly reduced as compared with those in the control mice.

Twenty-four hours after the administration of LPS, cytochrome P-450 $(0.45 \mathrm{nmol} / \mathrm{mg}$ of protein), NADPH-cytochrome $c$ reductase (28.4 $\mathrm{nmol} / \mathrm{min} / \mathrm{mg}$ of protein), aminopyrine $N$-demethylase $(0.21 \mathrm{nmol} / \mathrm{min} / \mathrm{mg}$ of protein), aniline hydroxylase $(0.12 \mathrm{nmol} / \mathrm{min} / \mathrm{mg}$ of protein), activation of cyclophosphamide ( $0.38 \mathrm{nmol} / \mathrm{min} / \mathrm{g}$ of liver), $9.000 \times \mathrm{g}$ supernatant protein $(64.5 \mathrm{mg} / \mathrm{g}$ of liver) and microsomal protein $(13.3 \mathrm{mg} / \mathrm{g}$ of liver) showed $44 \%, 53 \%, 45 \%, 38 \%, 61 \%, 73 \%$ and $79 \%$ of the control value, respectively.

On the other hand, in the successively LPS-treated mice, cytochrome P-450, NADPH-cytochrome $c$ reductase, aminopyrine $N$-demethylase, aniline hydroxylase, activation of cyclophosphamide, $9.000 \times \mathrm{g}$ supernatant protein and microsomal protein were $0.65 \mathrm{nmol} / \mathrm{mg}$ of protein. $43.7 \mathrm{nmol} /$ $\mathrm{min} / \mathrm{mg}$ of protein. $0.34 \mathrm{nmol} / \mathrm{min} / \mathrm{mg}$ of 

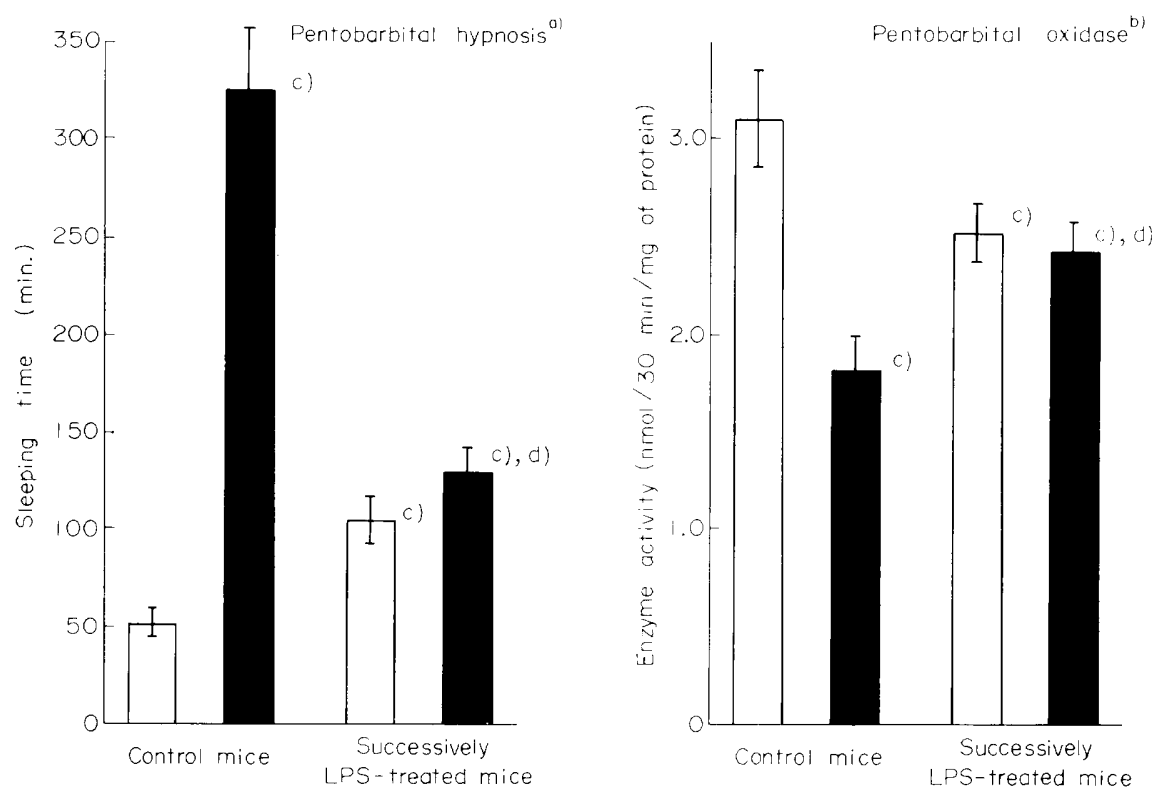

Fig. 1. Effect of an acute administration of LPS on pentobarbital-induced hypnosis and pentobarbital oxidase in the control mice and the successively LPS-treated mice. To form the successively LPS-treated mice, mice received six intraperitoneal injection of LPS on Day $1(5 \mathrm{mg} / \mathrm{kg})$, Day 2 (5 $\mathrm{mg} / \mathrm{kg})$. Day 3 $(10 \mathrm{mg} / \mathrm{kg})$, Day $4(10 \mathrm{mg} / \mathrm{kg})$, Day $5(20 \mathrm{mg} / \mathrm{kg})$, and Day $6(20 \mathrm{mg} / \mathrm{kg})$, respectively. The successively LPS-treated mice were studied on Day 7. The effects of a single administration of LPS (5 mg/ $\mathrm{kg}, \mathrm{i} . \mathrm{v}$.) were studied $24 \mathrm{hr}$ after the administration of LPS $(7,8)$. Control animals received the equal volume of saline. Duration of pentobarbital ( $50 \mathrm{mg} / \mathrm{kg}$, i.p.)-induced hypnosis was measured as the time elapsing from the loss of the obility to right itself from the supine position twice within 10 sec. a) Each bar represents the mean value \pm the standard error (S.E.) of 10-14 mice. b) Each bar represents the mean value $\pm S$. E. of four samples obtained from a pooled mixture of the livers of four mice. c) Significantly different from the control group by the $t$-test $(P<0.05)$. d) Significantly different from the group singly treated with LPS to the control mice by the $t$-test $(P<0.05)$. Symbols: $\square$ saline, LPS $(5 \mathrm{mg} / \mathrm{kg}$, i.v.).

protein, $0.23 \mathrm{nmol} / \mathrm{min} / \mathrm{mg}$ of protein, 0.49 $\mathrm{nmol} / \mathrm{min} / \mathrm{mg}$ of protein, $82.8 \mathrm{mg} / \mathrm{g}$ of liver and $16.7 \mathrm{mg} / \mathrm{g}$ of liver, respectively; each value was $63 \%, 81 \%, 73 \%, 74 \%, 77 \%, 94 \%$ and $99 \%$ of the control value, respectively.

However, when $5 \mathrm{mg} / \mathrm{kg}$ (i.v.) of LPS was administered to the successively LPStreated mice, no difference was observed in the hepatic drug-metabolizing enzyme activities as compared with those in the successively LPS-treated mice.

Effect of LPS on the lethality of aminopyrine, pentobarbital and cyclophosphamide and the analgesic action of aminopyrine in the successively LPS-treated mice: As shown in Table 2, when $5 \mathrm{mg} / \mathrm{kg}$ (i.v.) of LPS was administered to the control mice, the lethality of aminopyrine and pentobarbital and the analgesic action of aminopyrine increased, and in contrast, the lethality of cyclophosphamide decreased.

On the other hand, in the successively LPS-treated mice, the lethality of aminopyrine and pentobarbital and the analgesic action of aminopyrine slightly increased as compared with those in the control mice, and the lethality of cyclophosphamide slightly decreased.

However, in the successively LPStreated mice, no change of the lethality of aminopyrine, pentobarbital and cyclophosphamide and the analgesic action of aminopyrine was observed by the administration of LPS ( $5 \mathrm{mg} / \mathrm{kg}$, i.v.).

Effect of LPS on the blood sugar content in the successively LPS-treated mice: The 


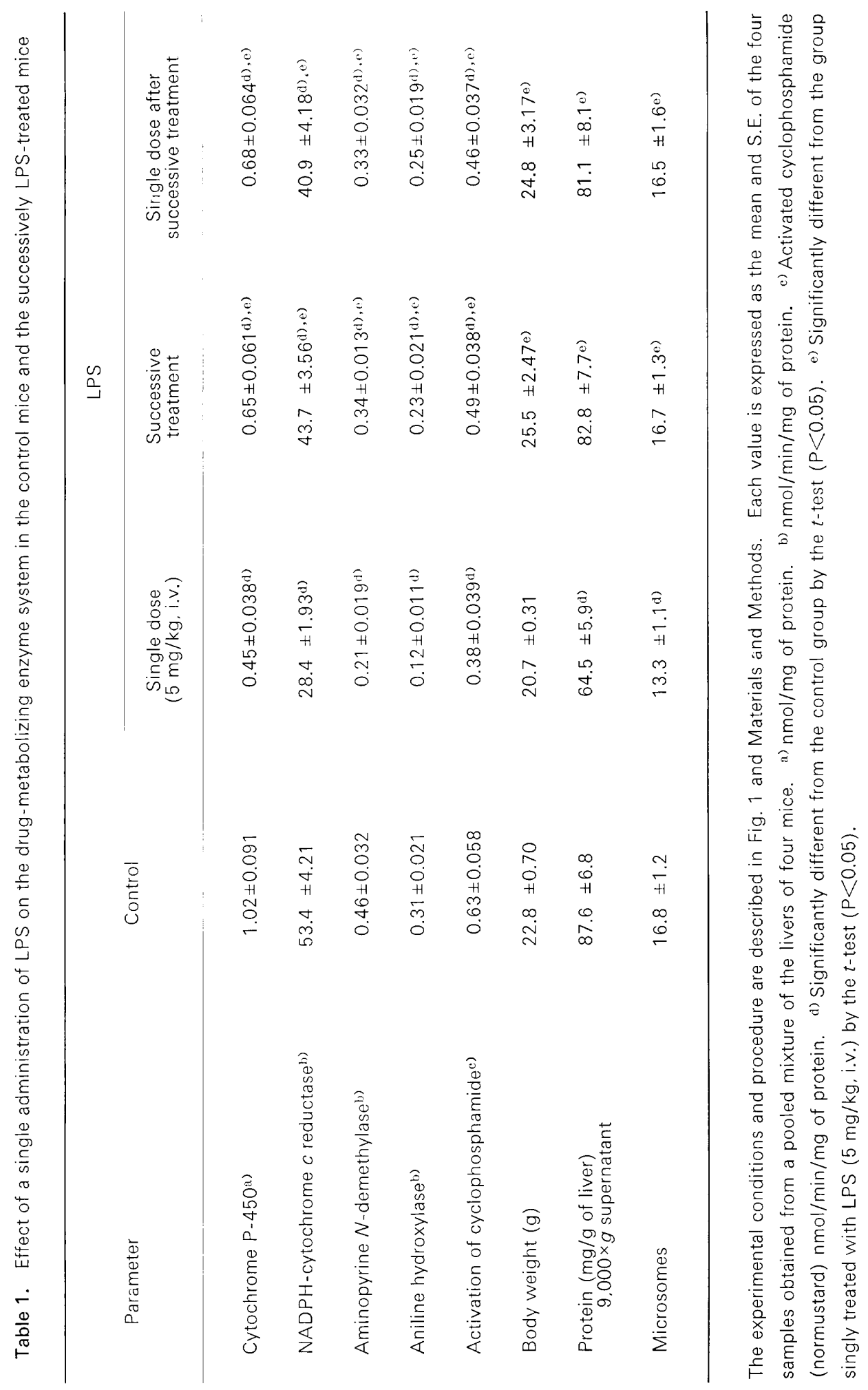


Table 2. Effect of a single administration of LPS on the toxicity of aminopyrine, pentobarbital and cyclophosphamide and analgesic action of aminopyrine in the control mice and the successively LPStreated mice

\begin{tabular}{|c|c|c|c|c|c|}
\hline \multirow{2}{*}{ Groups } & \multirow{2}{*}{$\begin{array}{c}\text { LPS } \\
\text { Single dose } \\
\mathrm{mg} / \mathrm{kg}\end{array}$} & \multicolumn{3}{|c|}{ LD50 $(\mathrm{mg} / \mathrm{kg})$} & \multirow{2}{*}{$\begin{array}{l}\text { ED50 }(\mathrm{mg} / \mathrm{kg}) \\
\text { Aminopyrine }\end{array}$} \\
\hline & & Aminopyrine & Pentobarbital & Cyclophosphamide & \\
\hline \multirow[t]{2}{*}{ Control mice } & 0 & $\begin{array}{c}274 \\
(226.8-331.5)\end{array}$ & $\begin{array}{c}163 \\
(129.7-206.1)\end{array}$ & $\begin{array}{c}546 \\
(431.3-689.0)\end{array}$ & $\begin{array}{c}77 \\
(60.0-99.9)\end{array}$ \\
\hline & 5 & $\begin{array}{c}163 \\
(130.5-205.6)\end{array}$ & $\begin{array}{c}112 \\
(85.7-147.8)\end{array}$ & $\begin{array}{c}687 \\
(550.0-859.5)\end{array}$ & $\begin{array}{c}32 \\
(25.7-40.9)\end{array}$ \\
\hline \multirow[t]{2}{*}{$\begin{array}{c}\text { Successively LPS- } \\
\text { treated mice }\end{array}$} & 0 & $\begin{array}{c}243 \\
(191.8-309.3)\end{array}$ & $\begin{array}{c}132 \\
(103.2-169.0)\end{array}$ & $\begin{array}{c}609 \\
(472.1-785.7)\end{array}$ & $\begin{array}{c}64 \\
(48.6-85.1)\end{array}$ \\
\hline & 5 & $\begin{array}{c}240 \\
(186.6-310.7)\end{array}$ & $\begin{array}{c}130 \\
(98.6-171.9)\end{array}$ & $\begin{array}{c}639 \\
(565.9-722.6)\end{array}$ & $\begin{array}{c}60 \\
(53.1-69.9)\end{array}$ \\
\hline
\end{tabular}

The experimental conditions and procedure are described in Fig. 1 and Materials and Methods. Test drugs were administered intraperitoneally.

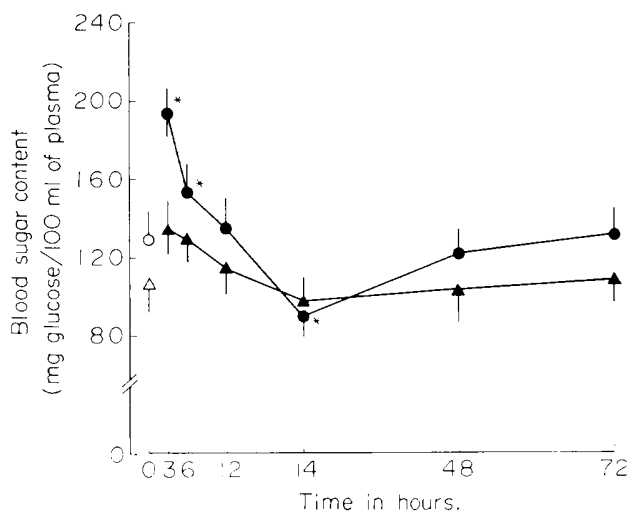

Fig. 2. Time course of blood sugar after a single administration of LPS in the control mice and the successively LPS-treated mice. The experimental conditions are described in Fig. 1. Mice in each group were sacrificed at the described time after the administration of LPS ( $5 \mathrm{mg} / \mathrm{kg}$, i.v.) or saline (0.1 $\mathrm{ml} / 10$ g. i.v.) Each point and vertical bar represent the mean and S.E. obtained from 6-8 mice. Symbols: - - control mice at the zero time. - - control mice+LPS (5 mg/kg, i.v.). - $\triangle-$ successively LPS-treated mice at zero time. - $\mathbf{A}-$ successively LPS-treated mice+ LPS (5 mg/kg, i.v.). * Significantly different from the control mice by the $t$-test $(P<0.05)$.

mean sugar content in the blood of the control mice was $128.6 \mathrm{mg} / 100 \mathrm{ml}$ of plasma $18 \mathrm{hr}$ after fasting. After an acute administration of LPS ( $5 \mathrm{mg} / \mathrm{kg}$, i.v.), dual changes in the blood sugar content were observed. That is to say, $3 \mathrm{hr}$ after the administration of
LPS, hyperglycemia (195.4 mg/100 $\mathrm{ml}$ of plasma) was observed, the value being 1.5 fold greater than that at the time of injection with LPS in the control mice; and $24 \mathrm{hr}$ after the administration of LPS, hypoglycemia (92.6 $\mathrm{mg} / 100 \mathrm{ml}$ of plasma) was observed, the value being three fourths of that at the time of injection with LPS in the control mice.

On the other hand, the blood sugar content of the successively LPS-treated mice was $105.7 \mathrm{mg} / 100 \mathrm{ml}$ of plasma $18 \mathrm{hr}$ after fasting, and it was lower than that of the control mice by $18 \%$. Also, after a single administration of LPS ( $5 \mathrm{mg} / \mathrm{kg}$, i.v.) to the successively LPS-treated mice, little change in the blood sugar content was observed.

\section{Discussion}

The present study demonstrated in mice that both acute and successive treatment with LPS increase the duration of hypnosis induced by pentobarbital and decrease the hepatic drug-metabolizing enzyme system (cytochrome P-450 content, the activities of NADPH-cytochrome $c$ reductase, pentobarbital oxidase, aminopyrine $N$-demethylase and aniline hydroxylase and activation of cyclophosphamide) as compared with those in the control mice, and the effects of an acute treatment with LPS in normal mice are greater than those in the successively LPStreated mice. The successively LPS-treated mice. however, were resistant to an acute dose of LPS. In successively LPS-treated 
mice, a kind of an LPS tolerant state was observed in the drug-metabolizing system.

Tolerance to LPS is a state of enhanced resistance produced by parenteral injection of LPS, and enhanced resistance is not related to a classic immune response (20). LPS tolerance is induced by the injection of one or several sublethal doses of LPS and renders the animal less susceptible to a challenge with LPS. LPS tolerance reaches maximum 24 or $48 \mathrm{hr}$ after the final injection of LPS and subsides gradually during a period of 1 to 2 months. Different criteria such as leukopinic, inhibition of leukocyte migration. induction of adrenal hemorrhage. Schwartzman reaction, tumor necrosis, hypotension, and enhancement of specific antibody have been employed to confirm the formation of LPS tolerance $(20,21)$. The mechanism of LPS tolerance is unclear. However, during this state of increased resistance, the reticuloendothelial system is stimulated as can be shown by measuring the blood clearance of bacteria, carbon particles or labeled endotoxin (20). Furthermore, LPS tolerance can be abolished by reticuloendothelial system blockade by thorotrast (20). For all these reasons, Beeson believed that this response was unrelated to antibody formation and stated that injection of endotoxin causes a change in the functional capacity of the reticuloendothelial system. whereby the ability to remove bacterial toxin from the blood is enhanced (20).

In addition, in acutely or successively LPS-treated mice, the lethality of aminopyrine and pentobarbital and the analgesic action of aminopyrine increased and the lethality of cyclophosphamide decreased as compared with those in the control mice. The acute LPS treatment to the successively LPS-treated mice, however, did not affect the hypnotic activity of pentobarbital and the toxicity and analgesic action of drugs.

The results are in good accordance with the paper of Abernathy et al. (22), in that both acute and successive treatment with LPS reduced the in vivo rates of hexobarbital and zoxazolamine metabolism in mice, and the effects of the acute treatment were greater than those of the successive treatment.

It is well known that LPS causes hyper- glycemia in mice in the early stage after the administration, but later it causes hypoglycemia $(23,24)$. In this report, we also examined the effect of LPS on blood sugar content in the successively LPS-treated mice and the control mice. Blood sugar content in the successively LPS-treated mice was lower than that in the control mice. When LPS was administered to the control mice, the well known effect of LPS which induced hyperglycemia in the early stage and hypoglycemia later was observed. However, little distinct influence on blood sugar was observed when LPS was administered to the successively LPS-treated mice.

Similar results were seen in the effect of LPS on the $\mathrm{Na}^{+}, \mathrm{K}^{+}$-ATPase of rat liver protoplasma membranes enriched with bile canaliculi (25). In that study, both acute and successive LPS treatment reduced the enzyme activity and the effects of the acute treatment were greater. However, when a single dose of LPS was administered to the successively LPS-treated rat, no change was observed on the activity of $\mathrm{Na}^{+}, \mathrm{K}^{+}$-ATPase of liver protoplasma membranes.

The effects of LPS on the microsomal drug-metabolizing enzyme system have been attributed to its interferon inducing abilities (26) or immunopotentiating activities (27). The former reasoning seems unlikely, however, since the microsomal drug-metabolizing enzyme activities were determined after giving LPS daily for 3 days, and it has been reported that interferon levels are low for more than 1 day when the LPS is given (28). The latter reasoning agrees with the report of Hojo et al. (29) that the treatment with zymosan, a typical immunopotentiator, brought about the depression of the hepatic microsomal drug-metabolizing enzyme activities and the stimulation of immunopotentiating activity, and these two activities responded oppositely to each other to an administration of zymosan, at least in the early stage.

However, the effects of immunopotentiators on hepatic drug-metabolism have not been so fully elucidated.

The depression of the hepatic drugmetabolizing enzyme system induced by the acute LPS-treatment (Table 1) are in agree- 
ment with other reports $(6,9)$.

It is reported in these studies that this depression was observed in suceesively LPS-treated mice. The inhibition of hepatic drug-metabolizing enzyme could also explain the resistance of the LPS-tolerant rats to carbon tetrachloride $\left(\mathrm{CCl}_{4}\right)$ (30), since the hepatic toxicity of $\mathrm{CCl}_{4}$ is largely dependent on its activation by the microsomal oxidative system (31).

The data as to the effect of LPS-treatment on the hepatic microsomal drug-metabolizing system are scant. Renton and Mannering (26) gave LPS ( $5 \mathrm{mg} / \mathrm{kg}$ ) to mice daily for 3 days, a regimen that is different from the usual tolerance-inducing schedule of increasing doses of LPS over several days (30). Accordingly, comparison of their results with ours is partly limited. Acute LPS treatment has been reported to impair the metabolism of sulfonamide (32), cyclophosphamide, aminopyrine and phenytoin (7, 8). Cyclophosphamide, aminopyrine and phenytoin are metabolized the hepatic microsomal drugmetabolizing system, and sulfonamide, however, is metabolized primarily by the conjugative reaction and not by microsomal oxidation (33).

Thus, the effect of LPS on sulfonamide metabolism may not be applicable to these studies, but Gorodischer et al. (6) and Sasaki et al. (8) reported that LPS also inhibited UDP-glucuronyltransferase activity.

A tolerance to LPS can be induced in man under experimental conditions (34), and it may develop in the clinical setting (35). Thus, the demonstration that the successive LPS treatment can decrease the in vivo metabolism of drugs in mice, if applicable to man, may be of clinical significance.

\section{References}

1 Pinsky, C., Hirshaut, Y. and Oettgen, H.: Treatment of melanoma by intratumoral injection of BCG. Natl. Cancer Inst. Monogr. 39, 225-228 (1973)

2 Nolan, J.P.: Role of endotoxin in liver injury. Gastroenterology 69, 1346-1356 (1975)

3 Green, S. and Dobrjansky, A.: Effect on the biochemistry of mouse serum and liver. J. Natl. Cancer Inst. 63, 497-502 (1979)

4 Farquhar, D., Loo, T.L., Gutterman, J.U., Hersh, E.M. and Luna, M.A.: Inhibition of drug me- tabolizing enzymes in the rat after BacillusCalmette-Guérin treatment. Biochem. Pharmacol. 25, 1529-1535 (1976)

5 Soyka, L.F., Hunt, W.G., Knight, S.E. and Foster, R.S., Jr.: Decreased liver and lung drugmetabolizing activity in mice treated with Corynebacterium parvum. Cancer Res. 36, 4425-4428 (1976)

6 Gorodischer, R., Krasner, J., McDevitt, J.J., Nolan, J.P. and Yaffe, S.J.: Hepatic microsomal drug metabolism after administration of endotoxin in rats. Biochem. Pharmacol. 25, 351353 (1976)

7 Sasaki, K., Saitoh, M. and Takayanagi, G.: Effect of lipopolysaccharide (E. coli) and OK-432. a Streptococcus preparation, on the hepatic drug-metabolizing system in mice. Yakugaku Zasshi 101, 932-938 (1981) (Abs. in English)

8 Sasaki, K., Saitoh, M. and Takayanagi, G.: Inhibition, of the hepatic cytochrome P-450dependent monooxygenase system by lipopolysaccharide (Escherichia coli) or Mycobacterium butyricum in mice. Oyo Yakuri 24, 717-730 (1982)

9 Yoshida, M., Egawa, K. and Kasai, N.: Effect of endotoxin arid its degradation products on hepatic mixed-function oxidase and heme enzyme system in mice. Toxicol. Lett. 12, 185190 (1982)

10 Bissell, D.M. and Hammakaar, L.E.: Cytochrome $\mathrm{P}-450$ heme and the regulation of hepatic heme oxygenase activity. Arch. Biochem. Biophys. 176, 91-102 (1976)

11 Sasaki, K., Saitoh, M. and Takayanagi, G.: Effect of lipopolysaccharide (Escherichia coli) or Mycobacterium butyricum on the hepatic $i$-aminolevulinic acid synthetase and heme oxygenase activity in mice. Oyo Yakuri 24,731 739 (1982)

12 Roberts, S.A., Miya, T.S. and Schnell, R.C.: Tolerance development to cadmium-induced alteration of drug action. Res. Commun. Chem. Pathol. Pharmacol. 14, 197-200 (1976)

13 Bornheim, L.M., Borys, H.K. and Karler, R.: Effects of cannabidiol on cytochrome P-450 and hexobarbital sleeping time. Biochem. Pharmacol. 30, 503-507 (1981)

14 Means, J.R., Schnell, R.C., Miya, T.S. and Bousquet, W.F.: Correlation of phenobarbitaland SKF-525A-induced modification of in vivo and in vitro pentobarbital metabolism in the rat. Pharmacology 16, 181-192 (1978)

15 Berry, L.J. and Smythe, D.S.: Some metabolic aspects of tolerance to bacterial endotoxin. J. Bacteriol. 90, 970-977 (1965) 
16 Hart, L.G., Adamson, R.H., Morris, H.P. and Fouts, J.R.: Stimulation of drug metabolism in various rat hepatomas. J. Pharmacol. Exp. Ther. 149, 7-15 (1965)

17 Sladek, N.E.: Metabolism of cyclophosphamide by rat hepatic microsomes. Cancer Res. 31, 901-908 (1971)

18 Lowry, O.H., Rosebrough, N.J., Farr, A.L. and Randall, R.J.: Protein measurement with Folin phenol reagent. J. Biol. Chem. 193, 265-275 (1951)

19 Sasaki, M.: An ultramicro-colorimetric method for the determination of plasma glucose with o-toluidine boric acid. Rinsho Byori 12, 434-437 (1964) (in Japanese)

20 Louis, C. and Monique, P.: Role of hypersensitivity and tolerance in reactions to endotoxins. In Microbial Toxins, Edited by Weinbaum, G., Kadis, S. and Ajl, S.J., Vol. IV, Bacterial Endotoxins, p. 437-459, Academic Press, New York and London (1971)

21 Saito, K.: Biological response. In Bacterial Endotoxins, Edited by Honmma, J.Y., Saito, K., Kasai, N. and Niwa, M., p. 447-460, Kodansha Scientific, Tokyo (1973) (in Japanese)

22 Abernathy, C.O., Zimmerman, H.J. and Utili, R.: Effects of endotoxin tolerance on in vivo drug metabolism in mice. Res. Commun. Pathol. Pharmacol. 29, 193-196 (1980)

23 Zeckwer, I.T. and Goodel, H.: Blood-sugar studies. I. Rapid alterations on the blood-sugar level of rabbits are results of intravenous injection of killed bacteria of various types. J. Exp. Med. 42, 43-56 (1925)

24 McCallum, R.E. and Berry, L.J.: Effects of endotoxin on gluconeogenesis, glycogen syrithesis, arid liver glycogen synthase in mice. Infect. Immunol. 7, 642-654 (1973)

25 Utili, R., Abernathy, C.O., Zimmerman, H.J. and Gaeta, G.B.: Hepatic excretory function in the endotoxin-tolerant rat. Proc. Soc. Exp. Biol. Med. 161, 554-558 (1979)

26 Renton, K.W. and Mannering, G.L.: Depression of hepatic cytochrome P-450 dependent monooxygenase system with administered interferon inducing agents. Biochem. Biophys. Res. Commun. 73, 343-348 (1976)

27 Chiller, J.M., Skimdmore, B.J., Morrison, D.C. and Weigle, W.O.: Relationship of the structure of bacterial lipopolysaccharides to its function in mitogenesis and adjuvanticity. Proc. Natl. Acad. Sci. U.S.A. 70, 2129-2133 (1973)

28 Giron, D.J., Lin, R.Y., Hempoll, F.E., Pindak, F.E. and Schmidt, J.P.: Role of interferon in the antiviral state elicited by selected interferon inducers. Proc. Soc. Exp. Biol. Med. 163, 146150 (1980)

29 Hojo, H., Suzuki, Y. and Uchiyama, M.: Effect of zymosan on hepatic drug metabolism in mice. Chem. Pharm. Bull. (Tokyo) 24, 10-15 (1976)

30 Nolan, J.P. and Ali, M.V.: Endotoxin and the liver. Il. Effect of tolerance on carbon tetrachloride induced injury. J. Med. 4, 28-38 (1973)

31 Diaz Gómez, M.I., Castro, J.A., de Ferreyra, E.C., D'Acosta, N. and de Castro, C.R.: Irreversible binding of ${ }^{14} \mathrm{C}$ from ${ }^{14} \mathrm{CCl}_{4}$ to liver microsomal lipids and proteins from rats pretreated with compounds altering microsomal mixed function oxygenase activity. Toxicol. Appl. Pharmacol. 25, 534-541 (1973)

32 Timar, M. Hädrich, I. and Teodorescu, M.: Studies of the metabolism of sulfametoxipirimidine in endotoxin tolerant mice. Biochem. Pharmacol. 21, 420-421 (1972)

33 Stowe, C.M. and Plaa, G.L.: Extrarenal excretion of drugs and chemicals. Annu. Rev. Pharmacol. 8, 337-356 (1968)

34 Utili, R., Abernathy, C.O. and Zimmerman, H.J.: Endotoxin effects on the liver. Life Sci. 20, 553568 (1977)

35 Tarao, K., So, K., Moroi, T., Ikeuchi, T., Sunayama, T., Endo, O. and Fukushima, K.: Detection of endotoxin in plasma arid ascitic fluid of patients with cirrhosis: Its clinical significance. Gastroenterology 73, 539-542 (1977) 